\title{
COMPLICATIONS OF INTRA ABDOMINAL DRAINS: A SINGLE CENTER EXPERIENCE
}

\author{
Muhammad Azhar, Munawer Latif Memon, Naeem Akhtar, Anam Altaf* \\ POF Hospital, Wah Cantt Pakistan, *Al-Shifa Trust Eye Hospital, Rawalpindi Pakistan
}

\begin{abstract}
Objective: To compare frequency of intra-abdominal complications in drainage and non-drainage group among patents who underwent intra-abdominal surgeries.

Study Design: Comparative prospective study.

Place and Duration of Study: Department of Surgery, Pakistan Ordinance Factory, Wah Cantt, from Mar 2018 to Jul 2018.

Methodology: There were 32 patients, 16 in each group. Patients were selected through the process of consecutive sampling. Patients were randomly divided into two groups (random number table method); group A patients underwent intra-abdominal drain while group B was non-drainage group. Patients were followed up for 7 days and observed for complications.

Results: Total 32 patients were included in the study. There were 14 (43.8\%) males and 18 (56.3\%) females. Mean age of patients was $43.2 \pm 9.5$ years. Drain group showed significantly low anastomosis leakage $(p=0.02)$, wound infection $(p=0.05)$, mortality $(p=0.04)$, pulmonary complications $(p=0.05)$ and bleeding $(p=0.03)$ as compared to the non-drain group.

Conclusion: Intra-abdominal drains are associated with several complications. Anastomosis leakage is the most common complication following pulmonary complications and bleeding. However, drains help in early detection of complications and timely management of such complications leads to better outcome of a surgical procedure.
\end{abstract}

Keywords: Anastomosis leakage, Complications, Intra-abdominal drain.

How to Cite This Article: Azhar M, Memon ML, Akhtar N, Altaf A. Complications of Intra Abdominal Drains: A Single Center Experience. Pak Armed Forces Med J 2021; 71(6): 2207-2210. ～Doi: https://doi.org/10.51253/pafmj.v71i6.4052

This is an Open Access article distributed under the terms of the Creative Commons Attribution License (https://creativecommons.org/licenses/by-nc/4.0/), which permits unrestricted use, distribution, and reproduction in any medium, provided the original work is properly cited.

\section{INTRODUCTION}

Abdominal drains are important surgical procedures used since centuries. Several years ago Hippocrates utilized different tubes for ascetic fluid removal from abdominal cavity. ${ }^{1}$ Theodore Billroth $\left(19^{\text {th }}\right.$ century) reported that after gastrointestinal surgery, peritoneal cavity drainage was essential for patient's life saving process. ${ }^{2}$ Literature reports that intraperitoneal collections (blood, pancreatic juice, bile, ascities, chyle and intestinal juice) were removed through prophylactic drains. These intraperitoneal collections (without drains) are associated with potential infection of adjacent tissues. Intra-abdominal drains are associated with wide acceptance and prevent gastrointestinal surgery complications. ${ }^{3}$

Intra-abdominal drains are used in colonic anastomosis, low pelvic anastomosis, and percutaneous drainage as therapy. Anastomotic leakage is the most common complication of intra abdominal drains. Anastomotic leakage is referred as radiological dehiscence present on post-operative enema. ${ }^{4}$ Tsujinaka et al, reported that radiological leakage is 3\% in drainage group as compared to no drainage group $(4 \%) .{ }^{5}$ Intraabdomi-

Correspondence: Dr Anam Altaf, House No. 254, MR-6, B-Block, B-17, Multigradens's, Islamabad Pakistan

Received: 30 Mar 2020; revision received: 19 Feb 2021; accepted: 15 Mar 2021 nal drainage complications were $7 \%$ in drainage group as compared to non-drainage group (4\%). ${ }^{6}$

Peritoneal cavity drainage is an effective prophylactic drainage (rectal surgery). Evidence shows that rate of anastomotic leakage is high in pelvic anastomosis as compared to colonic anastomosis. ${ }^{7}$ Eberhardt et $a l$, reported that anastomosis leakage is $3.2 \%$ patients of drainage group as compared to non drainage group (4\%). ${ }^{8}$ However, Law et al. reported that wound infection and pulmonary complications are common complication of drains with $1 \%$ mortality rate. ${ }^{9}$

American Society of Colon and Rectal Surgeons reported that ideal candidates for percutaneous drainage are patients with abscesses $>2 \mathrm{~cm} .{ }^{10}$ Local data on the complications of intra-abdominal drains is limited to reach any conclusion. Present study was planned to compare frequency of intra-abdominal complications in drainage and non drainage groups among patients who underwent intra-abdominal surgeries.

\section{METHODOLOGY}

A comparative prospective study was conducted at the department of Surgery, Pakistan Ordinance Factory (POF) Wah Cantt, from March to July 2018. A sample size of 32 patients (16 patients in each group) was calculated using $p 1=50 \%, p 2=10 \%, 80 \%$ power of study, 95\% confidence interval using WHO calcula- 
tor. ${ }^{11}$ Selection of patients was done through nonprobability consecutive sampling technique. Research approval was taken from research ethical committee (IRB no: RTS6790) of corresponding hospital. Consent forms were signed by all the participating patients.

Inclusion Criteria: Patients of age $>20$ years, both genders, who underwent abdominal surgeries including liver resection, cholecystectomy, pancreatic resection, esophageal, gastric and duodenal surgery, colorectal surgery and appendectomy were included in the study.

Exclusion Criteria: Patients with benign diseases, low anterior rectal resection emergency procedures, gross fecal peritoneal contamination, hemostatic packing, resection without anastomosis, colostomy closure, abscess, anastomosis above S3 and reversal of Hartman's procedure were excluded.

All the included patients underwent randomization to avoid selection bias using random number table. Group A patients received open or closed suction drains according to demand of surgical procedure while in group B no drain was used. Patients were followed for 7 days and observed for intra abdominal complications.

Data was analyzed by using Statistical Package for Social Sciences (SPSS) version 24. Mean \pm SD was calculated for continuous variable. Frequency and percentage was calculated for categorical variables. Chisquare test was used for measuring association between two groups. The $p$-value of $\leq 0.05$ was considered significant.

\section{RESULTS}

Total 32 patients were included in the study. There were $14(43.8 \%)$ males and $18(56.3 \%)$ females. Mean age of patients was $43.2 \pm 9.5$ years. There were $10(31.3 \%)$ patients in age group 21-40 years and 22 (68.8\%) in age group 41-65 years. Duration of disease was $\leq 6$ months in $11(34.4 \%)$ and $>6$ months in 21 $(65.5 \%)$ patients. There were $12(37.5 \%)$ patients with diabetes mellitus while $20(62.5 \%)$ patients were non diabetic. Out of all, 15 (46.9\%) patients were hypertensive while 17 (53.1\%) were non hypertensive. Among all the patients, $20(62.5 \%)$ stayed $\leq 2$ weeks in hospital while $12(37.5 \%)$ stayed $>2$ weeks in hospital. Among all the patients in groups (drain), 3 (9.4\%) had anastomosis leakage while $13(40.6 \%)$ did not show leakage. Among all the patients in group B (non-drain), 10 $(31.3 \%)$ showed anastomosis leakage while $6(18.8 \%)$ did not show any leakage $(p=0.02)$. Among all the patients in group A, 3 (9.4\%) showed wound infection, while $13(40.6 \%)$ did not show any infection. Among all the patients in group B, $8(25 \%)$ showed wound infection while $8(25 \%)$ did not show any infection $(p=0.05)$. Mortality was found to be significantly low in drainage group as compared to non-drainage group $(3.1 \%$ vs $12.5 \%, p=0.04)$ as shown in Table-I.

Among all the patients in drainage group, 2 $(6.3 \%)$ showed pulmonary complications while 14 $(43.8 \%)$ did not show pulmonary complications. Similarly, among all those in non-drainage group, $6(18.8 \%)$ showed pulmonary complications while $10(31.3 \%)$ did not show pulmonary complications $(p=0.05)$. Among all patients in drain group, $2(6.3 \%)$ showed bleeding while $14(43.8 \%)$ did not show bleeding. Among all the patients in non-drainage group, $9(28.1 \%)$ showed bleeding while $7(21.9 \%)$ did not show bleeding $(p=0.03)$. Hospital stay was $\leq 2$ weeks in $13(40.6 \%)$ patients and $>2$ weeks in $3(9.4 \%)$ patients in group A while in group B, hospital stay was $\leq 2$ weeks in $7(21.9 \%)$ patients and $>2$ weeks in $9(28.1 \%)$ patients $(p=0.02)$ as shown in Table-II.

Table-I: Comparison of complications in drain and non drain groups.

\begin{tabular}{|c|c|c|c|}
\hline \multirow[b]{2}{*}{ Complications } & \multicolumn{2}{|c|}{ Interventional Groups, n (\%) } & \multirow[b]{2}{*}{$\begin{array}{c}p- \\
\text { value }\end{array}$} \\
\hline & $\begin{array}{c}\text { Group A } \\
\text { (Drain) }\end{array}$ & $\begin{array}{c}\text { Group B } \\
\text { (Non drain) }\end{array}$ & \\
\hline \multicolumn{4}{|c|}{ Anastomosis Leakage } \\
\hline No & $13(40.6)$ & $6(18.8)$ & \multirow{2}{*}{0.02} \\
\hline Yes & $3(9.4)$ & $10(31.3)$ & \\
\hline \multicolumn{4}{|c|}{ Wound Infection } \\
\hline No & $13(40.6)$ & $8(25)$ & \multirow{2}{*}{0.05} \\
\hline Yes & $3(9.4)$ & $8(25)$ & \\
\hline \multicolumn{4}{|l|}{ Mortality } \\
\hline No & $15(46.9)$ & $12(37.5)$ & \multirow{2}{*}{0.04} \\
\hline Yes & $1(3.1)$ & $4(12.5)$ & \\
\hline
\end{tabular}

Table-II: Comparison of complications and hospital stay in drain and non drain group.

\begin{tabular}{|c|c|c|c|}
\hline \multirow[b]{2}{*}{ Complications } & \multicolumn{2}{|c|}{ Interventional Groups n (\%) } & \multirow[b]{2}{*}{$\begin{array}{c}p- \\
\text { value }\end{array}$} \\
\hline & $\begin{array}{c}\text { Group A } \\
\text { (Drain) }\end{array}$ & $\begin{array}{c}\text { Group B } \\
\text { (Non drain) }\end{array}$ & \\
\hline \multicolumn{4}{|c|}{ Pulmonary Complications } \\
\hline No & $14(43.8)$ & $10(31.3)$ & \multirow{2}{*}{0.05} \\
\hline Yes & $2(6.3)$ & $6(18.8)$ & \\
\hline \multicolumn{4}{|l|}{ Bleeding } \\
\hline No & $14(43.8)$ & $7(21.9)$ & \multirow{2}{*}{0.03} \\
\hline Yes & $2(6.3)$ & $9(28.1)$ & \\
\hline \multicolumn{4}{|l|}{ Hospital Stay } \\
\hline$\leq 2$ Weeks & $13(40.6)$ & $7(21.9)$ & \multirow{2}{*}{0.02} \\
\hline$>2$ Weeks & $3(9.4)$ & $9(28.1)$ & \\
\hline
\end{tabular}

\section{DISCUSSION}

Intra-abdominal drains are used for evacuation of contaminated fluid in human body. Several researchers 
believe that intra-abdominal drains can be used for tracking anastomosis integrity and help in diagnosis of early anastomotic complications (when excessive fluid or pus comes out through drains). ${ }^{12}$ Evidence exists that intra-abdominal and intraperitoneal hemorrhage could be detected through drains in post-operative duration. ${ }^{13-15}$

In the present study, anastomotic leakage was more common in non drainage group as compared to drainage group $(31.3 \%$ vs $9.4 \%, p=0.02)$. Bertelsen et al, reported that intra abdominal drains act as an eye to anastomosis by surgeons. They reported that out of all drains (20), only 1 contained enteric content and pus at the time of diagnosis with significantly low anastomotic leakage sensitivity (5\%). ${ }^{16}$ On the contrary, Matthiessen et al, reported that pelvic drains had high sensitivity in anastomotic leakage detection. ${ }^{17}$ Peeters et al, reported that anastomotic leakage was found in 10\% drainage and $18 \%$ non-drainage groups $(p=0.03) .{ }^{18}$ Tan et al, reported that male gender, smoking, lack of stoma, steroid use, preoperative radio or chemotherapy, emergency surgery, intra operative adverse events and severe bleeding are important risk factors for anastomosis leakage in intra-abdominal drains. ${ }^{19}$

In the present study, wound infection was significantly low in drainage group as compared to nondrainage group $(9.4 \%$ vs $25 \%, p=0.05)$. Galandiuk et al. reported that surgical site infections are common in patients undergoing intra-abdominal drains as compared to non drainage after colostomy $(10 \%$ vs $5 \%, p=$ 2.67). ${ }^{20}$ Merad et al, reported that infection at surgical wound accounts for $2.5 \%$ of intra-abdominal drainage complications. ${ }^{21}$ Another similar study reported that pain and drain site wound infections are associated with intra- abdominal drains $(p=0.01) .{ }^{22}$

In the present study, mortality was found to be significantly low in drainage group as compared to non-drainage group $(3.1 \%$ vs $12.5 \%, p=0.04)$. Sagar et $a l$, reported that patients undergoing colorectal surgeries did not show any significant difference in mortality of drainage and non-drainage groups ( $1 \%$ vs $2 \%$, $p=0.567) .{ }^{23}$

In the present study, pulmonary complications $(p=0.05)$ and bleeding $(p=0.03)$ were significantly high in non-drainage group as compared to drainage group. Kingham et al, reported that pulmonary complications were high in abdominal drainage group (19\%) as compared to no drainage $(1 \%)$ after liver resection. Moreover, bleeding and infected collection was high in abdominal drainage group (14\% and 11\%). ${ }^{24}$ Men et al, reported that patients who had intra-abdominal drains suffered bleeding as the $2^{\text {nd }}$ most common complication $(32 \%) .{ }^{25}$

\section{CONCLUSION}

Intra abdominal drains are associated with several complications. Anastomosis leakage is the most common complication following pulmonary complications and bleeding. However, drains help in early detection of complications and timely management of such complication leads better outcome of surgical procedure.

\section{Conflict of Interest: None.}

\section{Authors' Contribution}

MA: Data collection \& analysis, MLM: Write up, NA: Study interpretation, AA: Critical review.

\section{REFERENCES}

1. Robinson JO. Surgical drainage: a historical perspective. Br J Surg 1986; 73(2): 422-426.

2. Dougherty HH, Simmons RL. The biology and practice of surgical drains. Curr Probl Surg 1992; 29(3): 559-730.

3. Meakins JL. Innovations in surgery: the rules of evidence. Am J Surg 2013; 183(4): 399-405.

4. Averbach AM, Sugarbaker PH. The use of drains in elective surgery for colorectal cancer: always, never or selectively?. Tumori 2014; 81(3): 89-97.

5. Tsujinaka S, Kawamura YJ, Konishi F, Maeda T, Mizokami K. Pelvic drainage for anterior resection revisited: use of drains in anastomotic leaks. ANZ J Surg 2018; 78(6): 461-465.

6. Nesbakken A, Nygaard K, Lunde OC. Outcome and late functional results after anastomotic leakage following mesorectal excision for rectal cancer. Br J Surg 2016; 88(3): 400-404.

7. Branagan G, Finnis D. Prognosis after anastomotic leakage in colorectal surgery. Dis Colon Rectum 2015; 48(5): 1021-1026.

8. Eberhardt JM, Kiran RP, Lavery IC. The impact of anastomotic leak and intra-abdominal abscess on cancer-related outcomes after resection for colorectal cancer: a case control study. Dis Colon Rectum 2017; 52(3): 380-386.

9. Law WL, Choi HK, Lee YM, Ho JW, Seto CL. Anastomotic leakage is associated with poor long-term outcome in patients after curative colorectal resection for malignancy. J Gastrointest Surg 2017; 11(1): 8-15.

10. Urbach DR, Kennedy ED, Cohen MM. Colon and rectal anastomoses do not require routine drainage: a systematic review and meta-analysis. Ann Surg 2014; 229(2): 174-180.

11. Petrowsky H, Demartines N, Rousson V, Clavien PA. Evidencebased value of prophylactic drainage in gastrointestinal surgery: a systematic review and meta-analyses. Ann Surg 2014; 240(6): 1074-1084.

12. Yeh CY, Changchien CR, Wang JY, Chen JS, Chen HH, Chiang $\mathrm{JM}$ et al.Pelvic drainage and other risk factors for leakage after elective anterior resection in rectal cancer patients: a prospective study of 978 patients. Ann Surg 2015; 241(1): 9-13.

13. Boccola MA, Buettner PG, Rozen WM, Siu SK, Stevenson AR, Stitz R et al. Risk factors and outcomes for anastomotic leakage in colorectal surgery: a single-institution analysis of 1576 patients. World J Surg 2016; 35(1): 186-195.

14. Eberl T, Jagoditsch M, Klingler A, Tschmelitsch J. Risk factors for anastomotic leakage after resection for rectal cancer. Am J Surg 2018; 196(4): 592-598. 
15. Eriksen MT, Wibe A, Norstein J, Haffner J, Wiig JN. Anastomotic leakage following routine mesorectal excision for rectal cancer in a national cohort of patients. Colorectal Dis 2015; 7(1): 51-57.

16. Bertelsen CA, Andreasen AH, Jorgensen T, Harling H. Anastomotic leakage after anterior resection for rectal cancer: risk factors. Colorectal Dis 2018; 12(1): 37-43.

17. Matthiessen P, Hallbook O, Rutegard J, Simert G, Sjodahl R. Defunctioning stoma reduces symptomatic anastomotic leakage after low anterior resection of the rectum for cancer: a randomized multicenter trial. Ann Surg 2017; 246(2): 207-214.

18. Peeters KC, Tollenaar RA, Marijnen CA, Klein Kranenbarg E, Steup WH, Wiggers $\mathrm{T}$ et al. Risk factors for anastomotic failure after total mesorectal excision of rectal cancer. Br J Surg 2015; 92(2): 211-216.

19. Tan WS, Tang CL, Shi L, Eu KW. Meta-analysis of defunctioning stomas in low anterior resection for rectal cancer. Br J Surg 2019; 96(5): 462-472.
20. Galandiuk S, Fazio VW. Postoperative irrigation-suction drainage after pelvic colonic surgery. A prospective randomized trial. Dis Colon Rectum 2014; 34(3): 223-228.

21. Merad F, Hay JM, Fingerhut A, Yahchouchi E, Laborde Y, Pelissier E, et al. Is prophylactic pelvic drainage useful after elective rectal or anal anastomosis? A multicenter controlled randomized trial. French Association for Surgical Research. Surg 1999; 125(5): 529-535.

22. Sagar PM, Hartley MN, Macfie J, Mancey-Jones B, Sedman P, May J. Randomized trial of pelvic drainage after rectal resection. Dis Colon Rectum 2015; 38(3): 254-258.

23. Sagar PM, Couse N, Kerin M, May J. Randomized trial of drainage of colorectal anastomosis. Br J Surg 2014; 80(6): 769-771.

24. Kingham TP, Pachter HL. Colonic anastomotic leak: risk factors, diagnosis, and treatment. J Am Coll Surg 2009; 208(2): 269-278.

25. Men S, Akhan O, Koroglu M. Percutaneous drainage of abdominal abcess. Eur J Radiol 2014; 43(3): 204-218. 